\title{
Population genetics of Zostera noltii along the west Iberian coast: consequences of small population size, habitat discontinuity and near-shore currents
}

\author{
Onno E. Diekmann ${ }^{1}$, James A. Coyer ${ }^{2}$, Joao Ferreira ${ }^{1}$, Jeanine L. Olsen ${ }^{2}$, \\ Wytze T. Stam ${ }^{2}$, Gareth A. Pearson ${ }^{1}$, Ester A. Serrão ${ }^{1, *}$ \\ ${ }^{1}$ CCMAR - CIMAR Laboratório Associado, Universidade do Algarve, FCMA, Gambelas, 8005-139 Faro, Portugal \\ ${ }^{2}$ University of Groningen, Biological Center, PO Box 14, 9750 AA Haren, The Netherlands
}

\begin{abstract}
The effects of oceanographic patterns on marine genetic biodiversity along the SW Iberian Peninsula are poorly understood. We addressed the question of whether gene flow in this region depends solely on geographic distance between isolated patches of suitable habitat or if there are superimposed effects correlated with other factors such as current patterns. Zostera noltii, the dwarf eelgrass, is the keystone habitat-structuring seagrass species on intertidal mudflats along the Iberian west coast. We used 9 microsatellite loci to analyze population genetic diversity and differentiation for all existing 8 populations from NW Spain (Ria de Vigo) to SW Spain (Puerto Real, Cadiz). Populations are highly genetically differentiated as shown by high significant $F_{\mathrm{ST}}$, Wright's fixation index, (0.08 to 0.26$)$ values. A neighbor-joining tree based on Reynold's distances computed from allele frequencies revealed a split between northern and southern populations (bootstrap support of $84 \%$ ). This pattern of differentiation can be explained by (1) ocean surface current patterns present during $Z$. noltii's reproductive season which cause a dispersal barrier between the northern and southern populations of this region, (2) habitat isolation, due to large geographic distances between suitable habitats, preventing frequent gene flow, and (3) small effective population sizes, causing high drift and thus faster differentiation rates.
\end{abstract}

KEY WORDS: Phylogeography · Dwarf eelgrass · Seagrass conservation · Iberian Peninsula biogeography $\cdot$ Portuguese coast

\section{INTRODUCTION}

The Atlantic SW coast of the Iberian Peninsula is a biogeographical transition zone where many Atlantic marine species encounter their southern and northern limits, and Mediterranean species their western limits (European Register of Marine Species, www.vliz.be/ vmdcdata/erms/, and links therein). This coastal area exhibits a harsh combination of environmental conditions for soft sediment populations, due both to high levels of physical stress and to water motion-driven substrate instability, resulting in small, geographically isolated patches of suitable habitat which are mostly restricted to estuaries and coastal lagoons. In such habitats, seagrass communities play several key roles, for instance, they are primary producers, nurseries for important fish and shellfish populations, they filter suspended matter, and stabilize soft sediments.

Seagrass habitat is degrading worldwide due to anthropogenic disturbances, such as eutrophication, climate change, habitat destruction and coastal development (Short \& Wyllie-Echeverria 1996, Duarte 2002, Green \& Short 2003). Habitat loss and fragmentation of seagrass meadows may result in loss of genetic diversity (Reusch 2003), although moderate disturbance can also enhance genetic (genotypic) diversity (Hammerli \& Reusch 2003). Recovery of damaged seagrass communities may achieve biomass restoration through vegeta- 
tive growth, but reduction of genetic diversity can have serious effects on seagrass populations. Loss of genetic diversity can reduce the capacity of seagrasses to recover from perturbations or adapt to changing environmental conditions (Endler 1986, Williams 2001). In order to investigate the influence of disturbance on population structure and predict effects of future perturbations, understanding population genetic structure, diversity, and gene flow within and between natural populations is essential. Studies of Zostera marina have shown the need for genetic data in transplanting initiatives (e.g. Williams \& Davis 1996). Williams \& Orth (1998) showed that natural genetic diversity was distributed among various populations in the Chesapeake and Chinoteage Bays, and that it is not well represented by single populations. This type of knowledge is important for protection of seagrass meadows and to guide restoration initiatives (e.g. transplanting) of destructed areas (Williams 2001). It should however be noted that these studies used allozyme data that had little resolution to calculate genetic diversity.

Seagrasses can reproduce sexually through seeds and vegetatively through clonal propagation (Den Hartog 1970). The genetic structure of seagrass meadows is greatly influenced by the balance between seedling recruitment and clonal growth via rhizomes. Sexual reproduction introduces novel genotypes while asexual propagation ensures the spread of successful genotypes. However, it has often been suggested that sexual reproduction does not play an important role in seagrass propagation. This is attributed to low pollination success in hydrophilous flowering plants, limited dispersal of pollen and seeds, and low survival of seeds and seedlings (Les 1988, Laushman 1993, Hemminga \& Duarte 2000, Reusch 2003). Reusch (2000), however, found high outcrossing rates and multiple paternities in populations of the eelgrass Zostera marina from the German Wadden Sea, which suggests high pollination success, and contradicts the previous idea that sexual reproduction is not important in seagrasses. Pollen and seed dispersal, and especially seedling survival, appear to be the important limiting factors to sexual recruitment (Orth et al. 1994, Reusch 2003). These factors, in combination with extensive clonal growth, lead to the prediction that population differentiation will be significant. Geographic history and local environmental parameters act to further structure populations. This results in highly variable patterns of population genetic structure in seagrasses, even within populations of the same species (Reusch et al. 1998, Waycott 1998, Angel 2002, Reusch 2002). The clonal mode of propagation in seagrasses makes assessment of individual plants difficult. Genetic methods are therefore needed to distinguish genets (genetic individuals) from ramets (morphological individuals arising from vegetative reproduction) (Harper 1977).
Only then can proper analysis be performed to assess genotype diversity and gene flow. With the development of high-resolution DNA-based genetic markers it is possible to identify genets and ramets.

The dwarf eelgrass Zostera noltii Hornemann is an important perennial seagrass species on intertidal mudflats consisting of mud and detritus-rich fine sand. It is widely distributed, from Norway, south to the Mauritanian coast, just into the tropical region (Phillips \& Menez 1988, Green \& Short 2003), it is also present in the Mediterranean, the Black Sea, and even in the Caspian and Aral Seas (Den Hartog 1970). Z. noltii is an ideal seagrass species with which to investigate genetic differentiation among and between marine soft sediment populations along the west Iberian Peninsula coast, as it is a key species in such estuaries and coastal lagoons. These $Z$. noltii stands range from small fragmented patches to large continuous meadows, some of which are subjected to variable levels of disturbance, ranging from pristine undisturbed stable habitats to areas with unstable sediments and/or a high degree of several human-induced disturbances (e.g. increased nutrient input, dredging, clam digging and boats). These differences may be reflected in the genetic make-up of the various populations.

Along the West Iberian coast, Zostera noltii is restricted to estuaries and coastal lagoons separated by long stretches of unsuitable habitat. Populations are often separated by hundreds of kilometers. This pattern of large geographic distances between suitable habitat leads to the hypothesis that populations along this region may be highly differentiated, with low gene flow between them. The occurrence of a poleward current of warmer water (Relvas \& Barton 2002) during the reproductive season of this species might influence the populations located south of the Tagus estuary. This leads us to hypothesize that populations in this region should have a higher degree of connectedness between them than with those further north. We also hypothesize that there is high genetic drift due to small population sizes; this is magnified by habitat fragmentation and/or isolation.

The aim of the present study is to investigate these hypotheses by describing genetic variability and structure of all Zostera noltii populations that occur along the SW Atlantic Iberian coast (Cadiz to Galicia), inferred from the polymorphism of DNA microsatellites. Correspondence between the observed patterns and those predicted from geographic and oceanographic factors will be evaluated. The results from this study will provide a better understanding of the influence of nearshore oceanographic patterns and coastal topography along the SW Atlantic Iberian coast on the genetic diversity and structure of a marine species that plays a key role in ecosystem dynamics. 


\section{MATERIALS AND METHODS}

Sample collection. Zostera noltii samples were collected from 8 populations along the Iberian Peninsula coast (Fig. 1) ranging from Ria de Vigo in northern Spain to Puerto Real on the southern Spanish Atlantic coast (Table 1). Distances between populations along the coast range from 60 to about $1000 \mathrm{~km}$. Ramets were sampled at 50 random distances along a $60 \mathrm{~m}$ transect line and at randomly calculated distances to the left (max. $10 \mathrm{~m}$ ) or right (max. $10 \mathrm{~m}$ ) of the line, resulting in random sampling within a $20 \times 60 \mathrm{~m}$ sampling area $\left(1200 \mathrm{~m}^{2}\right)$. This way of sampling is only possible in fairly large continuous patches. When patches were small or fragmented, samples were taken in various ways; these are listed in Table 1.

DNA extraction, isolation, microsatellite amplification and locus scoring. Details of DNA extraction, isolation, microsatellite characterization and scoring of microsatellite loci can be obtained from Coyer et al. (2004a). In brief, genomic DNA was extracted from silica dried plant material by a CTAB $(2 \%$ hexadecyl trimethylammonium bromide) method. Nine microsatellite loci (Genbank accession codes: ZnB1 [AY566799], ZnB3 [AY566800], ZnB8 [AY566801], ZnD6 [AY566802], ZnE7 [AY566803], ZnF8 [AY566804], ZnF11 [AY566805]) were PCR amplified using fluorescently labeled primers. PCR products were visualized using an ABI-377 automated sequencer (Perkin-Elmer) and scored using Genescan software (Applied Biosystems).

Data analysis. Zostera noltii reproduces sexually and vegetatively. It is important to differentiate genets from ramets. Genetic diversity parameters such as inbreeding and heterozygosity can only be accurately assessed

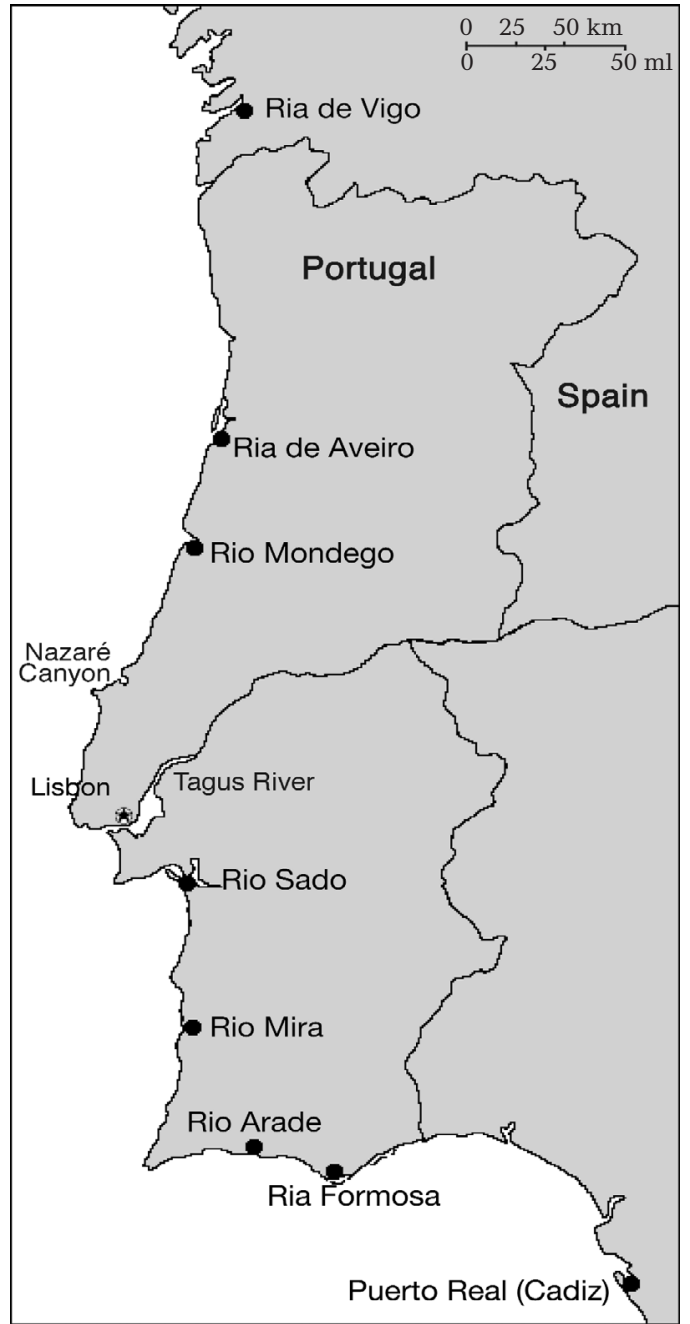

Fig. 1. Zostera noltii sampling sites along the Iberian Peninsula coast
Table 1. Sampling of Zostera noltii populations along the Iberian Peninsula coast from northern Spain into the Mediterranean. Distance refers to $\mathrm{km}$ along the coast from the northernmost population studied (Ria de Vigo). Irregular meadow shapes, dimensions, and patchiness made it impossible to use the exact same sampling scheme for all meadows. $Z$ noltii sampling scheme: 1 : Random sampling along a $20 \times 60 \mathrm{~m}$ area; 2 : samples taken haphazardly; 3 : same as (1) but random coordinates exceeding the patch width were taken on the edge of the patch; $_{\text {4 }}$ : two $25 \mathrm{~m}$ line transects with samples taken every $1.5 \mathrm{~m}$; 5: samples taken alternately, every 2.5 meters on each side of the patches edge; 6: samples taken every $3 \mathrm{~m}$ along a $150 \mathrm{~m}$ transect

\begin{tabular}{|c|c|c|c|c|}
\hline Site & Country & $\begin{array}{l}\text { Distance } \\
(\mathrm{km})\end{array}$ & $\begin{array}{l}\text { Meadow } \\
\text { morphology }\end{array}$ & $\begin{array}{l}\text { Sampling } \\
\text { method }\end{array}$ \\
\hline Ria de Vigo & Northern Spain & 0 & Patchy & 2 \\
\hline Ria de Aveiro & Portugal & 195 & Continuous & 3 \\
\hline Rio Mondego & Portugal & 255 & Continuous & 1 \\
\hline Rio Sado & Portugal & 505 & Patchy & 4 \\
\hline Rio Mira & Portugal & 605 & Continuous & 5 \\
\hline Rio Arade & Portugal & 720 & Continuous & 1 \\
\hline Ria Formosa & Portugal & 780 & Continuous & 1 \\
\hline Puerto Real & Southern Spain & 990 & Continuous & 6 \\
\hline
\end{tabular}

between genets. Multiple ramets of the same genet have to be removed prior to these analyses. Clonal diversity in a population was calculated as $P^{\prime} d=$ $\left[N_{\text {genotypes }}-1\right] /\left[N_{\text {samples }}-1\right]$ (modified after Ellstrand \& Roose 1987). In the case of a monoclonal population, $P^{\prime} d$ is no longer dependent on the sample size but diversity will be 0 for monoclonal meadows and 1 for those in which each sample exhibits a unique genotype.

Several descriptive statistics for within and between population genetic diversity were calculated using the GENETIX 4.04 program (Belkhir et al. 2001): number of alleles, observed heterozygosity $\left(H_{\text {obs }}\right)$, Nei's gene diversity (expected heterozygosity $\left(H_{\text {exp }}\right)$ (Nei 1987), as well as estimators of inbreeding 
$\left(F_{\mathrm{IS}}\right)$ and population differentiation $\left(F_{\mathrm{ST}}\right)$ (Wright 1969). Linkage disequilibrium (LD) was tested using Fisher's exact test as implemented in GENEPOP version 3.3 (Raymond \& Rousset 1995). Results were further analyzed using the $D$-statistics of Black and Krafsur (1985) as implemented in GENETIX 4.04 (Belkhir et al. 2001). Significance of $F_{\mathrm{IS}}$ and $F_{\mathrm{ST}}$ and LD was tested using permutations (10000 replicates). In LD permutations were followed by sequential Bonferroni correction (Rice 1989).

In order to further study genetic differentiation between populations (different sites) an assignment test was performed using Genclass 2.0 (Piry et al. 2004). Assignment tests are useful to detect recent immigration events (dispersal) and explore the direction of possible migration between populations. All individuals (genets) are assigned to the population site for which its probability of belonging is the highest (Paetkau et al. 1995, Cornuet et al. 1999). Firstgeneration migrants were detected by computing the likelihood ratio $\Lambda=L_{\mathrm{h}} / L_{\max }$, where $L_{\mathrm{h}}$ is the likelihood of drawing an individual from the population it was sampled from and $L_{\max }$ is the maximum likelihood observed for the individual in any population including the population it was sampled in (Paetkau et al. 2004). Probability calculations were done by a Monte-Carlo re-sampling (10 000 individuals) procedure (Paetkau et al. 1995, Ranalla \& Mountain 1997, Cornuet et al. 1999, Paetkau 2003). These methods assume random mating and linkage equilibrium within each population.

Pairwise distances were calculated from allele frequency data using Reynold's distances (Reynolds et al. 1983) in PHYLIP 3.6a3 (Felsenstein 2002 ${ }^{1}$ ). A neighborjoining tree was constructed with bootstrap resampling (10000 replications). More distant populations of Zostera noltii from Mauritania were used as outgroup species (Coyer et al. 2004b).

Correlation between genetic differentiation and geographic distance (isolation by distance) was tested in the IBD 1.2 program using 2000 randomizations (Bohonak 2002). According to suggestions by Rousset (1997) for a 2-dimensional space, a Mantel test was performed on estimates of $F_{\mathrm{ST}} / 1-F_{\mathrm{ST}}$ (Rousset 1997) using the $\theta$ estimator (Weir \& Cockerham 1984) in GENETIX 4.04 and the geographical distance. Reduced major axis (RMA) regression was used to determine the strength of the isolation. RMA is more appropriate than standard least-squares regression when the independent axis (geographic distance) is measured with error (Sokal \& Rohlf 1981, Hellberg 1994).

${ }^{1}$ Felsenstein J (2002) PHYLIP (Phylogeny Inference Package) version 3.6a3. Distributed by the author. Department of Genome Sciences, University of Washington, Seattle

\section{RESULTS}

\section{Genetic and genotypic diversity}

Genetic diversity over all 8 populations was high. A total of 372 individual Zostera noltii plants were genotyped for 9 microsatellite loci. This resulted in the identification of 233 genets and a total of 106 alleles. Average number of alleles per locus ranged from 4.7 to 7.2 (Table 2). All loci were polymorphic in all populations except for locus ZnE7, which was monomorphic in 2 populations, Rio Mondego and Rio Arade. Genotypic diversity was variable among populations ranging from $P^{\prime} d$ of 0.33 in Rio Arade to a $P^{\prime} d$ of 0.90 in the Rio Mira population (Table 2).

\section{Deviations from Hardy-Weinberg Equilibrium (HWE) and Linkage Disequilibrium (LD)}

All populations are in HWE except Rio Sado $\left(F_{\mathrm{IS}}=0.308\right)($ Table 2$)$. Significant LD was found in 5 (b1/b3, f11/b3, h10/b3, h10/f11 and h10/h8) out of 36 pairwise comparisons among 9 loci for all populations. However, further testing revealed that LD was due to drift $\left(\mathrm{D}_{\mathrm{IS}}<\mathrm{D}_{\mathrm{ST}}\right.$ and $\mathrm{D}_{\text {IS }}^{\prime}>\mathrm{D}_{\text {ST }}$ ) and not selection (after Black \& Krafsur 1985)

\section{Population differentiation}

Strong differentiation among the 9 populations was found as estimated by pairwise $F_{\mathrm{ST}}$ values (Table 3 ). $F_{\mathrm{ST}}$ ranged between 0.089 (Ria Formosa and Puerto Real, $112 \mathrm{~km}$ ) and 0.260 (Ria de Aveiro and Rio Arade, $295 \mathrm{~km})$. All pairwise comparisons were highly significant $(\mathrm{p}<0.001)$.

\section{Assignment test}

In the assignment tests $92 \%$ of the individuals were assigned to the population from which they were sampled. The $8 \%$ not assigned to their population of origin could not confidently be assigned to any other population. In the migration test 6 individuals (genets) were found to likely be first-generation immigrants. However, the results only indicate immigration between populations within the 2 regions, i.e. either south or north of the Tagus River, but not between them.

\section{Relationships among geographically distinct populations}

A neighbor-joining analysis (based on Reynold's distances and using Mauritania as an outgroup) on all 8 Zostera noltii populations that occur between Vigo and Cadiz revealed 2 clusters separating northern and 
Table 2. Clonal diversity, genetic variability and population differentiation $\left(F_{\mathrm{IS}}\right)$ estimates for 9 microsatellite loci in 8 Zostera noltii populations. N: total number of ramets analyzed; $\mathrm{n}$ : number of genotypes (genets); P'd: clonal diversity as calculated by [n-13]/[N-1]; $H_{\text {exp }}$ : expected heterozygosity; $H_{\text {obs }}$ : observed heterozygosity. $H_{\text {exp }} H_{\text {obs }} F_{\mathrm{IS}}$ and the average number of alleles per locus were calculated for all genets

\begin{tabular}{|c|c|c|c|c|c|c|c|c|c|c|}
\hline Population & $\mathrm{N}$ & $\mathrm{n}$ & $P^{\prime} d$ & $\begin{array}{l}\text { Genets with } \\
1 \text { ramet }\end{array}$ & $\begin{array}{l}\text { Genets with } \\
>1 \text { ramet }\end{array}$ & $\begin{array}{l}\text { Range of no. } \\
\text { of ramets }\end{array}$ & $H_{\text {exp }}$ & $H_{\mathrm{obs}}$ & $\begin{array}{l}\text { Average no. } \\
\text { alleles/locus }\end{array}$ & $F_{\mathrm{IS}}$ \\
\hline Ria de Vigo & 50 & 43 & 0.86 & 38 & 5 & $2-4$ & 0.5727 & 0.5762 & 7.2 & 0.005 \\
\hline Ria de Aveiro & 50 & 20 & 0.39 & 15 & 5 & $2-19$ & 0.4417 & 0.5556 & 4.8 & 0 \\
\hline Rio Mondego & 48 & 33 & 0.68 & 26 & 7 & $2-7$ & 0.5899 & 0.5455 & 5.7 & 0.091 \\
\hline Rio Sado & 30 & 24 & 0.79 & 19 & 5 & 2 & 0.5559 & 0.3981 & 4.7 & 0.308 \\
\hline Rio Mira & 50 & 45 & 0.90 & 42 & 3 & $2-4$ & 0.5993 & 0.5704 & 5.6 & 0.059 \\
\hline Rio Arade & 46 & 16 & 0.33 & 9 & 7 & $2-14$ & 0.5386 & 0.5764 & 4.8 & -0.038 \\
\hline Ria Formosa & 48 & 27 & 0.55 & 19 & 8 & $2-12$ & 0.6304 & 0.6255 & 5.9 & 0.027 \\
\hline $\begin{array}{l}\text { Puerto Real } \\
\text { (Cadiz, Spain) }\end{array}$ & 50 & 24 & 0.47 & 21 & 3 & $2-14$ & 0.6289 & 0.6528 & 6.8 & -0.017 \\
\hline
\end{tabular}

Table 3. Pairwise comparison of population differentiation $\left(F_{\mathrm{ST}}\right)$ among 9 populations of Zostera noltii. All $F_{\mathrm{ST}}$ values are significant $(\mathrm{p}<0.05)$

\begin{tabular}{|c|c|c|c|c|c|c|c|c|}
\hline Population & Ria de Vigo & Ria de Aveiro & Rio Mondego & Rio Sado & Rio Mira & Rio Arade & Ria Formosa & Puerto Real \\
\hline Ria de Vigo & - & 0.15787 & 0.14938 & 0.19111 & 0.24053 & 0.21926 & 0.14348 & 0.20655 \\
\hline Ria de Aveiro & & - & 0.11847 & 0.21993 & 0.21632 & 0.26001 & 0.18619 & 0.23170 \\
\hline Rio Mondego & & & - & 0.13932 & 0.22393 & 0.16967 & 0.12719 & 0.16683 \\
\hline Rio Sado & & & & - & 0.17190 & 0.14622 & 0.07854 & 0.1226 \\
\hline Rio Mira & & & & & - & 0.19385 & 0.13289 & 0.17390 \\
\hline Rio Arade & & & & & & - & 0.09513 & 0.10285 \\
\hline Ria Formosa & & & & & & & - & 0.08931 \\
\hline Puerto Real & & & & & & & & - \\
\hline
\end{tabular}

southern populations (bootstrap $=84$ ), with a separation along the region of the Tagus River estuary (Fig. 2). Within the northern and southern cluster, population structure remained unresolved.

\section{Isolation by distance (IBD)}

Significant IBD (Mantel test, $\mathrm{p}<0.016$ ) was observed among all populations under consideration (0 to $990 \mathrm{~km}$ ), and $24 \%$ of the variation in the data is explained by geographic distance (Fig. 3). When populations south of the Tagus River were considered, no significant IBD was observed $(p<0.549)$. This indicates that IBD is mostly explained by the north-south distinction. IBD could not be calculated for the northern populations since only 3 populations are available.

\section{DISCUSSION}

Along SW Iberia, populations of Zostera noltii vary greatly in clonal diversity, ranging from a few large individuals, clones or genets (Rio Arade $P^{\prime} d=0.33$ ), to populations with many small individuals, where almost

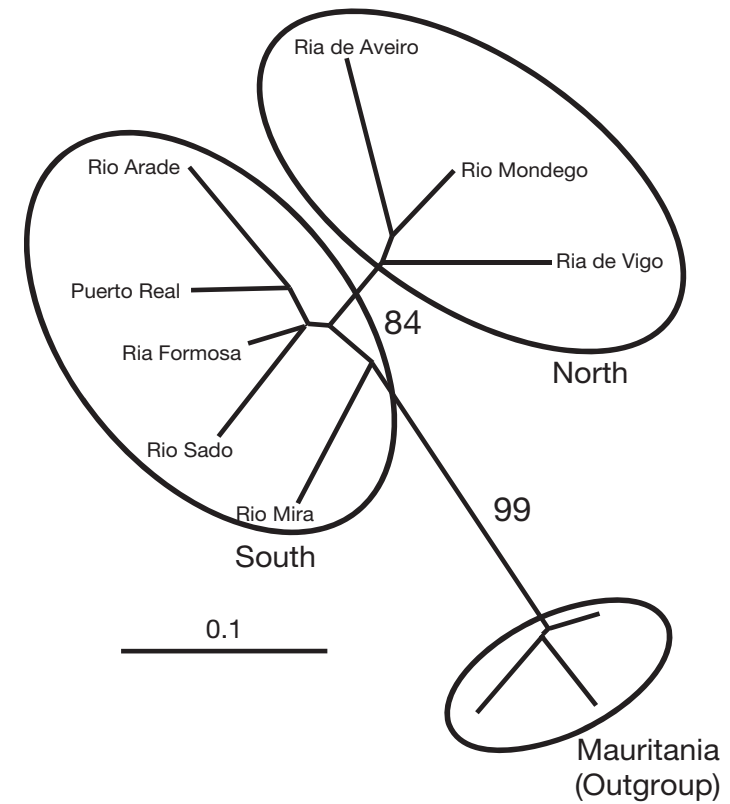

Fig. 2. Neighbor-joining tree illustrating the relationship among Iberian Zostera noltii populations. The tree was based on pair wise Reynold's distances (Reynolds et al. 1983) between genets only. Only bootstrap values $>50 \%$ are shown (10000 permutations). Mauritania populations were used as the outgroup 
each plant sampled consisted of a unique genotype that arose from a different seed (Rio Mira, $P^{\prime} d=0.90$ ), with a mean $P^{\prime} d$ of 0.62 . Clonal diversity for $Z$. marina populations in the Iberian Peninsula (Ria Formosa) was much lower than in $Z$. noltii (Billingham et al. 2003), with $P^{\prime} d$ s ranging from 0.0 to 0.67 with a mean $P^{\prime} d$ of 0.18 (recalculated from Billingham 2003). Iberian meadows of both Zostera species are often small and patchy, and therefore in both our study and that of Billingham et al. (2003), clonal diversities were estimated from samples that in most cases covered the entire meadow. This result may thus be a biogeographic effect; the southern limit of $Z$. marina populations is along the southern coast of Portugal, but this represents the center of $Z$. noltii's distributional range.

Genetic diversity $\left(H_{\text {exp }}\right)$ and allelic richness (no. alleles/locus) do not show any distinct pattern along the Iberian coast but the mean gene diversity $(0.57 \pm 0.06)$ and allelic richness $(5.7 \pm 0.9)$ are among the highest found within the distribution range of Zostera noltii as described in Coyer et al. (2004b). They found a general decline in genetic diversity from Mauritania to Denmark along the Atlantic coast, which was related to range expansion from southern refugia after the last glacial maximum (10000 b.c.). However, unexpected high diversity was found in the Dutch Wadden Sea and on the German island of Sylt. An explanation for this phenomenon could be disturbance (Coyer et al. 2004 b). In Z. marina high genetic diversity was also found in the Dutch Wadden Sea and the German island Sylt (Olsen et al. 2004) but was found to be low in Portuguese populations in the Ria Formosa. These populations are thought to be genetically impoverished as a consequence of isolation, patchiness and

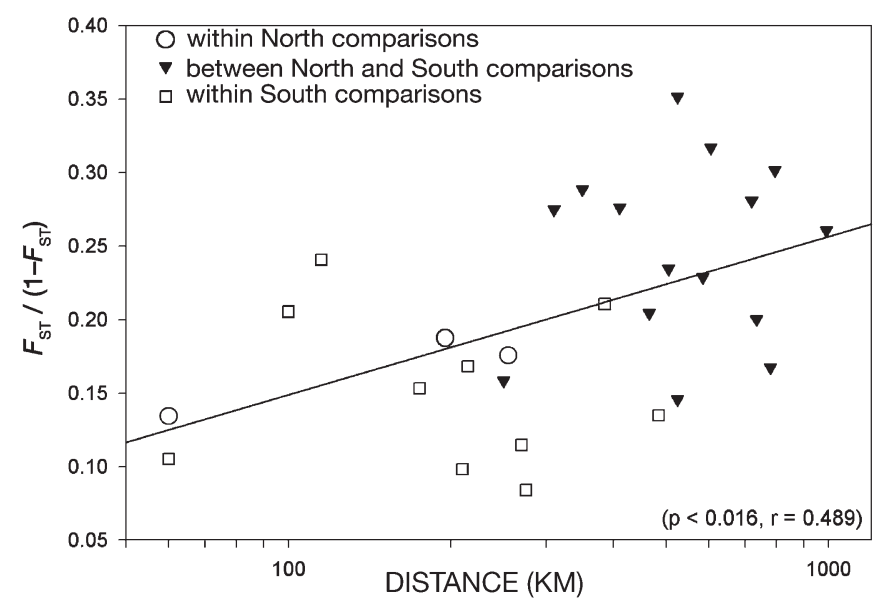

Fig. 3. Isolation by distance based on pairwise comparisons of genetic and geographic (log scale) distance among 8 populations. Linear best fit is shown. Genetic and geographic matrices were compared with the Mantel test and 10000 randomizations; $\mathrm{p}$-value is shown temperature stress, characteristics that are frequently observed in populations at their distributional limits.

Populations of Zostera noltii along the SW Iberian coast appear to be highly differentiated as shown by high $F_{\mathrm{ST}}$ values. Furthermore, populations in the south are more connected to each other than to populations in the north and vice versa. Populations of $Z$. noltii are found mostly in secluded estuaries or lagoons with narrow access to the open sea and are separated by long stretches of unsuitable habitat, like beaches and rocky shores, tens to hundreds of kilometers apart. These circumstances are probably the main cause of the low gene flow observed between $Z$. noltii populations. However, the relatively high genetic diversity found in $Z$. noltii populations indicates that sexual reproduction plays an important role in these populations. Factors preventing reproductive plant parts from dispersing to other areas therefore appear to be the main reason for lack of connectivity between populations.

Surface currents probably also play an important role in the structuring of populations of Zostera noltii. Populations south of the Tagus River have a higher degree of connectedness between them than those further north (Fig. 3). Sea surface currents along the Iberian Peninsula coast mediate strong upwelling and subsequent water movements perpendicular to shore (Fiuza 1983). This may cause dispersal directed more perpendicular to shore and subsequently low dispersal along the shore. During spring and summer, which is the reproductive season for Z. noltii, upwelling is more intense and persistent off the western coast than the southern coast. A coastal warm water counter-current runs south to north from the Gulf of Cadiz along the southern Portuguese coast (Relvas \& Barton 2002), sometimes as far as the Rio Sado, creating an obstacle to dispersal between northern and southern populations. Additionally, the equatorward current of cold water becomes separated from the coast around the latitudes of the Tagus River (Sanchez \& Relvas 2003). There are 2 other features that can function as geographical barriers and may increase the effect of coastal currents on dispersal and gene flow. First, there is the Tagus River, which flows into the Atlantic, affecting near-shore currents and salinity, and may prevent transport of $Z$. noltii propagules or (reproductive) vegetative fragments across the river mouth. The second barrier is the Nazaré Canyon. This is an underwater canyon that nearly reaches shore. It has been hypothesized that the Nazaré Canyon changes seawater circulation patterns (Gomes et al. 2001), which might prevent $Z$. noltii from bridging the gap between north and south. Gomes et al. (2001) found a distinct pattern of differentiation between orthern and southern groundfish assemblages that corresponds with oceanographic differences north and south of the Tagus-Nazaré region. A similar pattern of differentiation was found in the red alga 
Gelidium sesquipedale (Alberto et al. 1999). A distinction between populations of this algal species north and south of the Tagus River was shown in a neighborjoining tree based on RAPD markers. The patterns of distribution in G. sesquipedale were attributed to upwelling in combination with coastal surface currents. The present study is the first to relate the poleward Cadiz current to marine genetic biodiversity.

Besides the role of oceanic currents, other explanations cannot be ruled out as possible causes for the observed differentiation. Populations of Zostera noltii are isolated, mostly small, and the level of clonality is variable between populations; therefore effective population size $\left(\mathrm{N}_{\mathrm{e}}\right)$, at least in some populations, is likely to be low. Consequently, genetic drift is likely to be high in these populations. High differentiation suggests that gene flow is low but it could be mostly due to high drift. So even though suggestions of low gene flow imply low probability of recolonization after local extinctions, if drift is driving most differentiation, then migration might still be relevant. Isolation by distance suggests that some migration is taking place between neighboring populations, even across the Tagus/Nazaré barrier, although with lower frequency in the latter case. However, the assignment tests show no evidence for migration across the barrier, so it is likely to be very infrequent, possibly dependent on random events or very rare favorable conditions for transport of propagules.

In small isolated clonal populations there is a higher chance of local extinction. If extinction is followed by a stochastic recolonization event, a founder effect, this would likely cause the resulting populations to be highly differentiated. Our results imply that populations rely on their neighboring populations for recolonization and maintenance of genetic diversity. Loss of neighboring populations, i.e. decreases in connectedness, lowers the chance of dispersal and therefore makes populations even more vulnerable to extinction (Newman \& Pilson 1997). Genetic drift drives population differentiation, and this is expected to be stronger when there is low gene flow to counteract drift effects, as we have found to be the case for Iberian populations of Zostera noltii. In this situation it is likely that populations will become too different to function as donor populations in restoration practices. Knowledge of genetic diversity will enable proper selection of appropriate donor populations. However, genetic diversity alone will not guarantee success in restoration initiatives (Williams 2001). The next step will be to collect information on the linkage of genetic diversity with fitness related characters such as sexual reproduction and growth rate. This information will greatly increase transplantation success.

In conclusion, this study has shown that populations of Zostera noltii along the Iberian Peninsula coast are highly differentiated and there is a clear difference between northern and southern populations with the major barrier coinciding with the Tagus River/Nazaré Canyon region. Gene flow takes place mostly between neighboring populations, but not enough to breakup inter-population differentiation, and rarely occurs across the north-south geographical barrier. Sea surface current patterns especially during the $Z$. noltii reproductive season may help explain the limited gene flow detected between northern and southern populations. The realization that oceanographic currents may act as barriers to dispersal is not new, but given the central position of SW Iberia as a biogeographic transition zone and as a refugium during the ice ages, the identification of oceanographic barriers and of other factors affecting gene flow in this region takes on particular importance in understanding such sharp biogeographic boundaries.

Acknowledgements. We thank Prof. P. Relvas for discussion and information about current patterns along West Iberia, and Dr. S. Arnaud-Haond for helpful comments. This research was supported by the European Union project EVK3-CT2000-00044 (Monitoring and Management of Seagrasses, M\&MS), the FCT-Portuguese Science Foundation project PNAT/1999/BIA/15003/C (SEAGRASSRIA), the Center for Ecological and Evolutionary Studies (CEES), University of Groningen, Haren, The Netherlands, and a post-doctoral fellowship funded by the FCT, Portugal, and the European Social Fund (ESF) to O.E.D. (SFRH/BPD/9454/2002).

\section{LITERATURE CITED}

Alberto F, Santos R, Leitão JM (1999) Assessing patterns of geographic dispersal of Gelidium sesquipedale (Rhodophyta) through RAPD differentiation of populations. Mar Ecol Prog Ser 191:101-108

Angel R (2002) Genetic diversity of Halodule wrightii using random amplified polymorphic DNA. Aquat Bot 74: 165-174

Belkhir K, Borsa P, Chikhi L, Raufaste N, Bonhomme F (2001) GENETIX 4.02, logiciel sous Windows TM pour la génétique des populations. Laboratoire Génome, Populations, Interactions, CNRS UMR 5000, Université de Montpellier II, Montpellier

Billingham MR, Reusch TBH, Alberto FA, Serrão E (2003) Is reproduction more important at geographical limits? A genetic test of the seagrass Zostera marina in the Ria Formosa, Portugal. Mar Ecol Prog Ser 265:77-83

Black WC, Krafsur ES (1985) A Fortran program for the calculation and analysis of two-locus linkage disequilibrium coefficients. Theor Appl Genet 70:491-496

Bohonak AJ (2002) IBD (Isolation By Distance): a program for analyses of isolation by distance. J Hered 93:153-154

Cornuet JM, Piry S, Luikart G, Estoup A, Solignac M (1999) New methods employing multilocus genotypes to select or exclude populations as origins of individuals. Genetics 153:1989-2000

Coyer JA, Reusch TBH, Stam WT, Serrão EA, Pearson G, Procaccini G, Olsen JL (2004a) Characterization of microsatellite loci in the dwarf eelgrass Zostera noltii (Zosteraceae) and cross-reactivity with Z. japonica. Mol Ecol Notes 4:497 
Coyer JA, Diekmann OE, Serrão EA, Procaccini G, Milchakova N, Pearson G, Stam WT, Olsen JL (2004b) Population genetics of dwarf eelgrass Zostera noltii throughout its biogeographic range. Mar Ecol Prog Ser 281:51-62

Den Hartog C (1970) Sea-grasses of the World. North-Holland Publishing, Amsterdam

Duarte CM (2002) The future of seagrass meadows. Environ Conserv 29:192-206

Ellstrand NC, Roose ML (1987) Patterns of genotypic diversity in clonal plant species. Am J Bot 74:123-131

Endler JE (1986) Natural selection in the wild. Princeton University Press, Princeton, NJ

Fiuza AF (1983) Upwelling patterns off Portugal. In: Suess E, Thiede J (eds) Coastal upwelling. Plenum Publishers, New York, p 85-87

Gomes MC, Serrão E, Borges MF (2001) Spatial patterns of groundfish assemblages on the continental shelf of Portugal. ICES J Mar Sci 58:633-647

Green EP, Short FT (2003) World atlas of seagrasses. University of California Press, Berkeley

Hammerli A, Reusch TBH (2003) Inbreeding depression influences genet size distribution in a marine angiosperm. Mol Ecol 12:619-629

Harper GL (1977) Population biology of plants. Academic Press, New York

Hellberg ME (1994) Relationships between inferred levels of gene flow and geographic distance in a philopatric coral, Balanophyllia elegans. Evolution 48:1829-1854

Hemminga M, Duarte C (2000) Seagrass ecology. Cambridge University Press, Cambridge

Laushman RH (1993) Population genetics of hydrophilous angiosperms. Aquat Bot 44:147-158

Les DH (1988) Breeding systems, population structure and evolution in hydrophilous angiosperms. Ann Mo Bot Gard 75:819-835

Nei M (1987) Molecular evolutionary genetics. Columbia University Press, New York

Newman D, Pilson D (1997) Increased probability of extinction due to decreased genetic effective population size: experimental populations of Clarkia pulchella. Evolution 51:354-362

Olsen JL, Stam WT, Coyer JA, Reusch TBH and 14 others (2004) North Atlantic phylogeography and large-scale population differentiation of the seagrass Zostera marina L. Mol Ecol 13:1923-1941

Orth RJ, Luckenbach M, Moore KA (1994) Seed dispersal in a marine macrophyte: implications for colonization and restoration. Ecology 75:1927-1939

Paetkau D (2003) An empirical exploration of data quality in DNA-based population inventories. Mol Ecol 12: 1375-1387

Paetkau D, Calvert W, Stirling I, Strobeck C (1995) Microsatellite analysis of population structure in Canadian polar bears. Mol Ecol 4:347-354

Paetkau D, Slade R, Burden M, Estoup A (2004) Direct, realtime estimation of migration rate using assignment methods: a simulation-based exploration of accuracy and power. Mol Ecol 13(1):55-66

Phillips RC, Menez EG (1988) Seagrasses. Smithson Contrib

Editorial responsibility: Otto Kinne (Editor-in-Chief), Oldendorf/Luhe, Germany
Mar Sci 34:1-104

Piry S, Alapetite A, Cornuet, JM, Paetkau D, Baudouin, L, Estoup A (2004) GeneClass2: a software for genetic assignment and first generation migrants detection. J Hered 95:536-539

Rannala B, Mountain JL (1997) Detecting immigration by using multilocus genotypes. Proc Natl Acad Sci USA 949197-9201

Raymond M, Rousset F (1995) An exact test for population differentiation. Evolution 49:1280-1283

Relvas P, Barton ED (2002) Mesoscale patterns in the Cape São Vicente (Iberian Peninsula) upwelling region. J Geophys Res, Vol 107 (C10), 1364, doi:10.1029/20000JC000456

Reusch TBH (2000) Pollination in the marine realm: microsatellites reveal high outcrossing rates and multiple paternity in eelgrass Zostera marina. Heredity 85:459-464

Reusch TBH (2002) Microsatellites reveal high population connectivity in eelgrass (Zostera marina) in two contrasting coastal areas. Limnol Oceanogr 47:78-85

Reusch TBH (2003) Floral neighbourhoods in the sea: how floral density, opportunity for outcrossing and population fragmentation affect seed set in Zostera marina. J Ecol 91: 610-615

Reusch TBH, Stam W, Olsen JL (1998) Size and estimated age of genets in eelgrass, Zostera marina, assessed with microsatellite markers. Mar Biol 133:519-525

Reynolds J, Weir BS, Cockerham C (1983) Estimation of the coancestry coefficient: basis for a short-term genetic distance. Gen Soc Am 105:767-779

Rice WR (1989) Analyzing tables of statistical tests. Evolution 43:223-225

Rousset F (1997) Genetic differentiation and estimation of gene flow from F-statistics under isolation by distance. Genetics 145:1219-1228

Sanchez RF, Relvas P (2003) Spring-summer climatological circulation in the upper layer in the region of Cape St. Vincent, southwest Portugal. ICES J Mar Sci 60:1232-1250

Short FT, Wyllie-Echeverria S (1996) Natural and human-induced disturbance of seagrasses. Environ Conserv 23:17-27

Sokal RR, Rohlf FJ (1981) Biometry, 2nd edn. WH Freeman, New York

Waycott M (1998) Genetic variation, its assessment and implications to the conservation of seagrasses. Mol Ecol 7: 793-800

Weir BS, Cockerham CC (1984) Estimating F-statistics for the analysis of population structure. Evolution 38:1358-1370

Williams SL (2001) Reduced genetic diversity in eelgrass transplantations affects both population growth and individual fitness. Ecol Appl 11:1472-1488

Williams SL, Davis CA (1996) Population genetic analyses of transplanted eelgrass (Zostera marina) beds reveal reduced genetic diversity in southern California. Restor Ecol 4:163-180

Williams SL, Orth RJ (1998) Genetic diversity and structure of natural and transplanted eelgrass populations in the Chesapeake and Chincoteague bays. Estuaries 21: $118-128$

Wright S (1969) Evolution and the genetics of populations, Vol 2. University of Chicago Press, Chicago

Submitted: April 28, 2004; Accepted: December 21, 2004

Proofs received from author(s): March 18, 2005 